DOE/NASA/20370-79/19

NASA TM-79291

\title{
PHOTOVOLTAIC POWER SYSTEM RELIABILITY CONSIDERATIONS
}

Vincent R. Lalli

National Aeronautics and Space Administration

Lewis Research Center

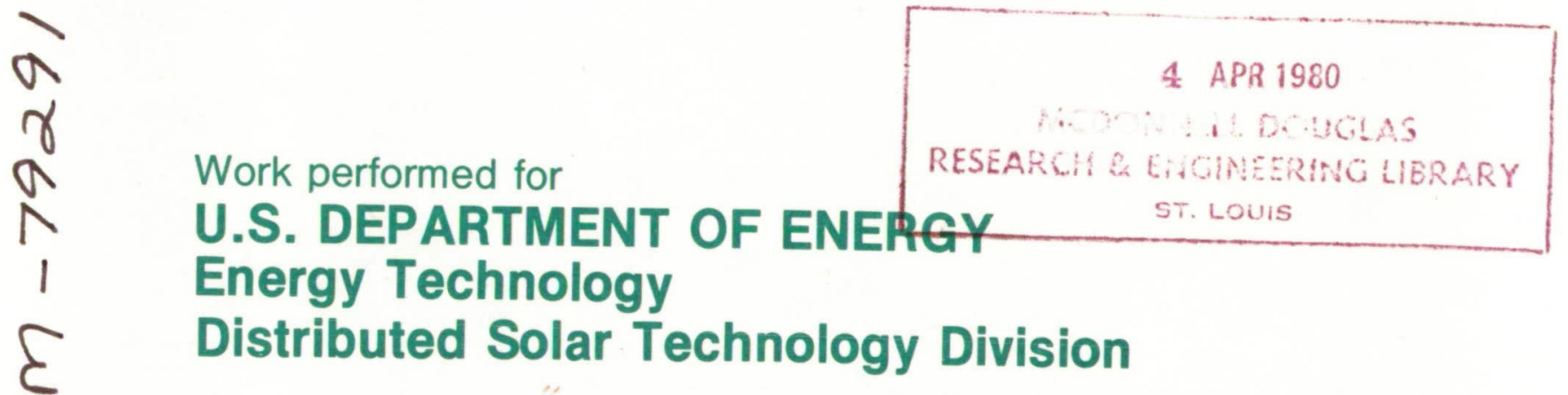

I

4

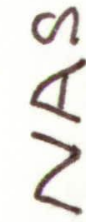

Prepared for

Annual Reliability and Maintainability Symposium

San Francisco, California, January 22-24, 1980 
NOTICE

This report,was prepared to document work sponsored by the United States Government. Neither the United States nor its agent, the United States Department of Energy, nor any Federal employees, nor any of their contractors, subcontractors or their employees, makes any warranty, express or implied, or assumes any legal liability or responsibility for the accuracy, completeness, or usefulness of any information, apparatus, product or process disclosed, or represents that its use would not infringe privately owned rights. 
DOE/NASA / 20370-79/19

NASA TM-79291

PHOTOVOLTAIC POWER SYSTEMS

RELIABILITY CONSIDERATIONS

Vincent R. Lalli

National Aeronautics and Space Administration

Lewis Research Center

Cleveland, Ohio 44135

Prepared for

U。S。DEPARTMENT OF ENERGY

Energy Technology

Distributed Solar Technology Division

Washington, D, C。 20545

Under Interagency Agreement $D E-A B 29-76 E I 20370$

Annual Reliability and Maintainability Symposium

San Francisco, California, January 22-24, 1980 
Vincent $\cdot R$. Lalli; NASA Lewis Research Center; Cleveland

Key Words: Photovoltaic, Power, Reliability, Design, Failure modes, Inspection

\section{Abstract}

This paper describes an example of how modern engineering an' safety techniques can be used to assure the reliable and safe operation of photovoltaic power systems. This particular application was for a solar cell power system demonstration project in Tangaye, Upper Volta, Africa, one of two photovoltaic village power projects currently managed by the Photovoltaic Project office. The techniques involve a definition of the power system natural and operating environment, use of design criteria and analysis techniques, an awareness of potential problems via the inherent reliability and FMEA methods, and use of a fail-safe and planned spare parts engineering philosophy. The Tangaye system has been operating since March 1,1979 . This is the second photovoltaic system designed to provide electric power requirements for remote villages. The first village power system was installed at Schuchuli, Arizona in December 1978.

\section{Introduction}

The objective of the Federal Solar Energy Program is to accelerate the development of economical solar energy systems so that solar energy will become a viable technological alternative to other forms of energy. To achieve this objective requires advancing the technology as well as addressing the nontechnological issues which, if not understood and planned for, could deter the use of solar energy. The primary challenge for the designer of solar cell power systems is production of a low-cost solar energy system that operates unattended, is reliable, maintainable, and environmentally acceptable. In meeting this challenge, the designer is faced with multiple design requirements which must be satisfied during the design process. Among the most important of these requirements is system availability. From the outset of the program, the designer must address, in a formal and disciplined way, the issues associated with availability of the hardware, compatibility with the environment, and safety of the public and the construction and maintenance personnel.

The Agency for the International Development (AID) of the Department of State, the Department of Energy (DOE), and the National Aeronautics and Space Administration are currently operating two village power solar cell power system demonstration projects of $1.8 \mathrm{~kW}$ and $3.5 \mathrm{~kW} .^{1}$ Availability was a primary consideration in these two solar cell power system demonstration projects.

The reliability methodology and disciplined approach to design is best exemplified in the complexprograms which have safely transported man to the moon. This approach embodies a program where all functions design, fabrication, assembly, checkout, and operations - are controlled by formal procedures, rigorous design reviews, and the close scrutiny of independent safety, reliability, and quality organizations.

Modern solar cell power systems are a combination of standard commercial practices of the electric power and construction industries and advanced aerospace technologies related to solar cells, computer analysis, material, checkout, and operations. As such, solar cell power systems should be relatively troublefree and cost effective. The reliability techniques developed in the aerospace industry have been applied in a selective manner. These methods made it possible to recognize both the unique and standard commercial characteristics of the system components. The process used to assure reliability in the design and operation of solar cell power systems, using the village power system in Tangaye, Africa as an illustrative example, is described in this paper.

\section{System Description}

The Tangaye system is depicted in figure 1. This system consists of a solar array, batteries, controls, instrumentation, power distribution panel, and loads. The solar array, batteries, and loads for the system operate at a nominal 120 volts dc. Controls and instrumentation for the system operate at 12 volts dc. Use of dc systems avoids the costs, complexities, and losses associated with dc/ac inverters while 120 volts minimizes line losses and permits the use of comercially available dc switches and motors. All electrical load devices were individually selected on the basis of energy efficiency. Solar array and battery sizes were determined using a NASA/LeRC developed computerized solar system simulation program. The program combines solar cell characteristics, average monthly insolation and atmospheric data, and an hourly load profile to determine hourly battery depth-of-discharge (DOD) as a function of array size, tilt angle, and battery capacity. It also incorporates. a factor for module output losses due to dirt and encapsulant darkening and a subroutine to randomly vary insolation within selected limits to develop worst-case DOD conditions.

The $1.8 \mathrm{~kW}$ (peak) Tangaye silicon solar cell array consists of twelve 1.22 by $2.44 \mathrm{~m}$ panels each containing eight modules connected in series to form a 120-volt string. The panels are designed for $160 \mathrm{~km} / \mathrm{hr}$ ( $96 \mathrm{mph}$ ) winds and are bolted together from commercially available steel channels and hardware. There are three rows of four panels each mounted to triangular structures whose base legs are buried and anchored about $0.3 \mathrm{~m}$ below grade. This design eliminates the need for concrete and minimizes excavation. The insolation characteristics at Tangaye (latitude $13^{\circ}$ ) allow nearly maximum array output at a single tilt angle $\left(11^{\circ}\right)$.

There are two batteries used in this system: the main (120 v) battery capacity of the Tangaye system is $540 \mathrm{Ah}$, and the instrumentation and control (I/C) battery capacity is $200 \mathrm{Ah}$. The Tangaye I/C battery is charged from a separate 12 -volt, $74 \mathrm{~W} \mathrm{PV}$ array. Calculated worst-case DOD for the main battery is 30 percent. The batteries are located in a vented room in the Mill/ Battery Building.

This system uses lead-calcium grid battery cells specifically designed for deep cycling operation. Leadcalcium cells were selected for low gas evolution, low self-discharge, high charge efficiency, and constant charge voltage over the lifetime of the cell.

Voltage regulation and battery charge control are accomplished by array string switching. Each series string in the array is connected to the main bus through a relay. A controller senses system voltage and commands a programmable drum relay to disconnect (open circuit) or connect series strings to keep system voltage 
at or below the maximum safe battery charge-voltage. An alternative duty cycle regulator control can perform the same function. Over- and under-voltage protection is also provided. If system voltage goes above or below limit voltages, the array or loads are disconnected. Alarm lights are provided to indicate these conditions. The Tangaye system contains three loads: a flour mill and a light located in a Mill/Battery Building, and a water pump. System size (i.e., array peak power and battery capacity), mill size, and mill operating time per day were based on limitations of available funds. Water pumping was assumed to be limited by the $5-\mathrm{m}^{3} /$ day measured yield of the well.

A 1/4-hp, 120-volt dc permanent magnet motor drives a positive displacement jack-type pump which can deliver $1.5 \mathrm{~m}^{3} / \mathrm{hr}$ from the shallow (10.7 m deep) well to a $6-\mathrm{m}^{3}$ water storage tank. The water tank has five faucets attached to a pipe located along its side. The pump motor is controlled by water level sensors in the tank and in the bottom of the well.

A 1-hp, 120-volt dc permanent magnet motor drives the flour mill. A timer allows the mill to operate up to a cumulative total of 8 hours per day. The mill, a burr type, is capable of grinding about $40 \mathrm{~kg} / \mathrm{hr}$ of fine-ground flour, or $320 \mathrm{~kg} / 8-\mathrm{hr}$ day, which is enough for about 640 people per day. A dual 20-watt fluorescent lamp is located in the milling room.

The Tangaye system is completely instrumented. A complete set of panel meters displays system parameters. The panel meters are read daily by designated individuals in the village. Data are forwarded to LeRC from Tangaye.

Baseline socio-economic studies have been completed in the village. Socio-economic changes at Tangaye will be monitored by U.S. AID personnel with a final indepth study also to be performed at the end of a year of system operation.

A "groupment" (co-op) consisting of about 60 village families has been formed to manage the milling operation. The membership fee is 500 French South African Franks (FrCFA $-\$ 2.50$ ). Charges for milling are set by the groupment and are competitive with mills in nearby villages. Mills in other villages are powered by hand or diesel systems. Milling is open to member and nonmember families alike. Proceeds from membership and milling are used to pay two full-time millers and to accumulate funds for spare parts and repairs after the first year of operation. Once adequate funds are established, profits will be distributed to groupment members.

\section{System Reliability Requirements and Program Implementation}

NASA Lewis senior management requested that the Office of Reliability and Quality Assurance assist the Photovoltaic Project office to deliver hardware that would be reliable and safe. Figure 2 shows the relationship of R\&QA with the Photovoltaic office.

These offices worked together and identified, evaluated, and either eliminated or controlled undesired system events with the potential to:

1. Damage system or support equipment and facilities

2. Injure personne1

3. Render system unavailable

These reliability and safety issues were accomplished by: identifying the equipment functions and operations that may result in undesired events; assessing those events for impact and probability; by instituting methods to eliminate those events by reducing the event to an acceptable risk; and by verifying implementation of control measures in design, operating controls and procedures for installation, test, and maintenance.

\section{Reliability Approach, Analysis, and Verification}

Figure 3 illustrates the disciplines used to as- sure the reliability of the solar cell power system. The approach used was to produce a design that could fail-safe and be repaired from spare parts in a short time. 2

The Tangaye power system was deployed in a specific location and physical environment. In order to assure that the power system was capable of reliable operation in this expected environment, elements of the system were purchased or designed to meet applicable environmental criteria specified in Table $I$.

One method to improve product reliability is to provide safety margins applied to the environmental and operating needs. A power system can exhibit a variety of failure modes during operation or testing. Each failure mode detected was evaluated individually.

System design was subjected to a critical review by the staff technical disciplines. Many of the components used in this solar cell power system have been in use for many years with an established reliability record.

Those components which were classed as new designs were analyzed to determine their inherent reliability. Common practice is to represent part integrity or reliability in terms of failure rate or mean-time-betweenfailure (MTBF). ${ }^{3}$ The reliability analys is were then performed by a reliability specialișt and reviewed by the cognizant engineer and the system engineers. The current authoritative failure rate data published by the Department of Defense in MIL-HDBK-217A and B was used.

Figure 4 shows a sample calculation for the pulse width modulated circuit for the duty cycle voltage regulator. This circuit is used to regulate the array voltage by switching photovoltaic panels on or off according to line needs. Thermal stresses for these boards were verified experimentally by infrared inspection. New components that have a reliability less than 0.96 for a 5-year operating life were considered as candidates for the 1 ist of mandatory components for spare parts. Actual field service data for the many off-theshelf components used in this system defined maintenance requirements and mandatory spare parts.

Another integral part of the preliminary design process is the conduct of a failure mode and effects analyses (FMEA), wherein many possible failure modes are identified, their effects analyzed and corrective actions taken as appropriate to preclude the undesirable consequences. The FMEA sheets were completed by the reliability specialist and reviewed by system engineers and cognizant designers. An example of one of the 25 major components that was analyzed in the FMEA is shown in figure 5. Review of the FMEA by the designers resulted in design changes to either prevent failure modes or reduce their impact.

Each component was reviewed by the reliability specialist to determine: failure modes, causes, effects, corrective action, and special remarks:applicable to the component from the manufacturer for our application of their component. This analysis was conducted on many of the solar cell power system components, including major items such as the drum programmer and smaller items like relays and resistors. The failure mode data was taken directly from field experience whenever such data was available. About 50 failure modes were identified and corrective actions were implemented where necessary to reduce system down-time.

In addition to directly affecting the design of the solar cell power system, the FMEA is a valuable tool in developing checkout, inspection, and maintenance requirements and procedures. Components critical to the fail-safe philosophy are identified. Special attention is given to these components during assembly, checkout, and maintenance to assure reliable performance and that nacessary spare parts will be available when needed.

As in most programs, fabrication and installation 
are critical phases in the solar cell power system program. During these activities it is important to assure that the power system is built with the specified quality and that testing verifies that the system meets all requirements. Assurance responsibility during these activities lies with the Product Assurance Organization. $P l$ ans and requirements for a quality system consistent with cost are documented and inspection procedures have been established. Each hardware component was functionally verified to be within specification in a similar solar power system at LeRC. This testing assures that the system is properly interfaced and that the control system hardware is functioning per the specification requirements.

After complete verification testing and demonstration in all operating modes and completion of user training, the system is turned over to the operating personnel.

\section{Concluding Remarks}

The modern solar cell power system is a product of the procedures, practices, and technology developed and used by the utility, construction, and aerospace industries. Development of solar energy as an acceptable, low-cost energy source requires solar cell power systems to demonstrate reliable, safe operation. The reliability assurance program developed for these systems makes use of the lessons learned from these industries and the safety, reliability, and quality assurance tools developed by them.

The operational reliability of solar cell power systems is directly related to the prevention of single point failure modes. These failure modes are aggravated by the variable environment to which the power system is subjected and the need to operate and maintain the system for maximum availability.

To meet these challenges, an engineering reliability program was developed and utilized. This program involves a definition of the solar cell power system natural and operating environments, use of design criteria and analysis techniques, an awareness of potential problems via the inherent reliability and FMEA methods, and the use of a fail-safe and planned spare parts engineering philosophy. It is expected that this program, when coupled to an effective quality assurance and system checkout program, will demonstrate that solar energy systems, such as the village power system in Africa, will meet the reliability and safety objectives of the Federal Solar Energy Program.

The Tangaye system has been operating since

March 1, 1979. As of September 15, 1979, the system had achieved a 0.82 availability with a mean repair time of 11 days. A major down-time problem occurred when a timer for the drum programmer failed with the wrong spare parts on hand. Running water has been extremely popular with the villagers. Groupment members plus nonmenbers and women coming to the Tangaye market ensure a steady workload at the mill. The installation has been the center of considerable interest and activity and the villagers are considering other enterprises for the area to further capitalize on the system.

This is one of the first photovoltaic systems designed to provide community electric power requirements. As such it is a prototype of systems which should find extensive application in developing countries througout the world.

\section{References}

1. A. F. Ratajczak, W. J. Bifano, "Description of Photovoltaic Village Power Systems in the United States and Africa," DOE/NASA/20485-79/1, April 1979.
2. D. H. Reilly, "Safety Considerations in the Design and Operation of Large Wind Turbines," DOE/NASA/20305$79 / 3$, June 1979 .

3. Anon, "Reliability for the Engineer," Margin Marietta Corp., Orlando, Florida, 1965.

\section{Bibliography}

V. R. Lalli

NASA Lewis Research Center

21000 Brookpark Road

Cleveland, Ohio 44135

M.S. $500-211$

Vincent R. Lalli was born in Garfield Heights, Ohio on Octuber 16, 1931. He received his B.S. and M.S. degree in Electrical Engineering from C.W.R.U. in 1953 and 1959, respectively. As a Research Assistant at Case and later at Picatinny Arsenal, he engaged in the development of electronic fuses and special devices. In 1956 he joined TRW, where he worked as design, lead and group engineer. In 1963 he joined NASA as an Aerospace Technologist. He is now responsible for Reliability Engineering in line with his recent work for the Product Assurance directorate in design, analysis, and failure studies. He has taught courses in electrical engineering and statistics at various universities. He is a member of Sigma Xi, Eta Kappa Nu, is a Registered Professional Engineering in the State of Ohio, and a senior member of the IEEE (S'50,M'56,SM'65): 


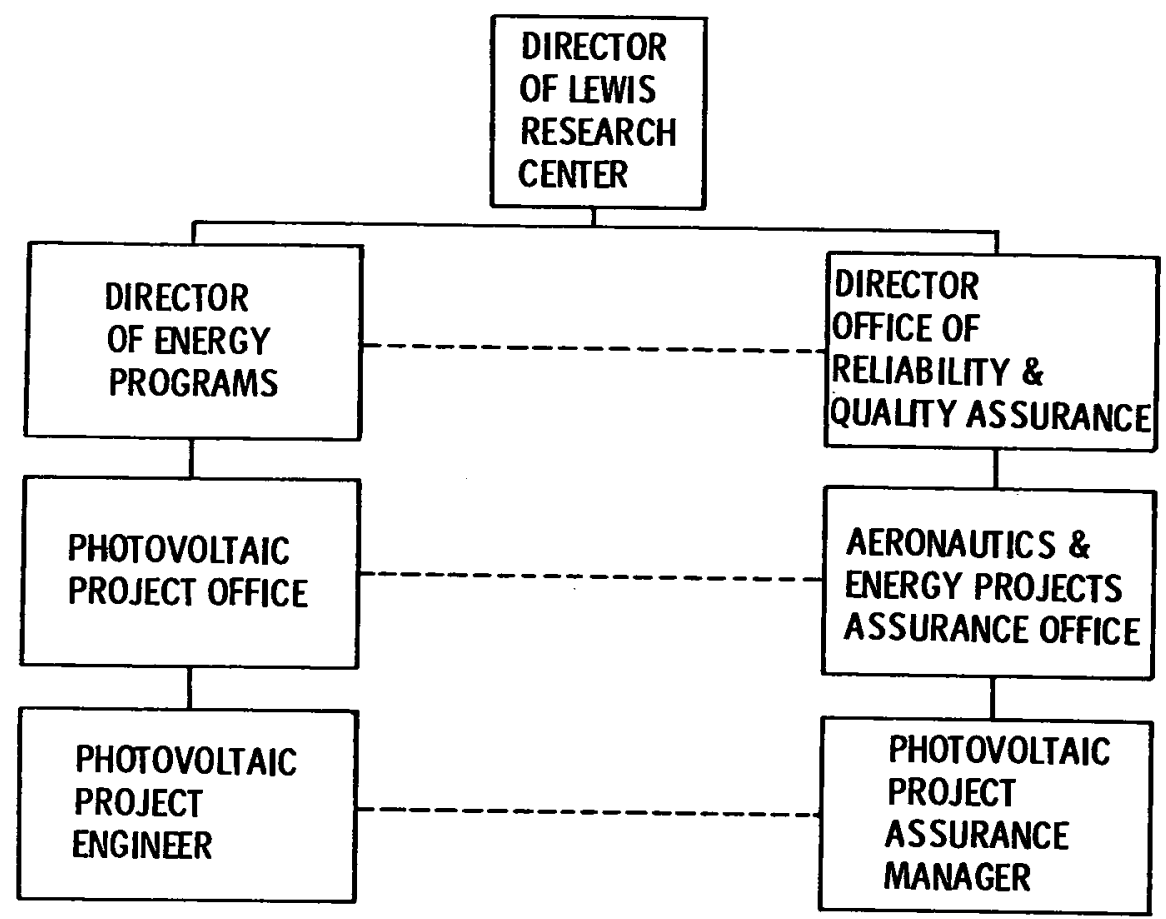

Figure 2 - Relationship of R\&QA with Photovoltaic office.

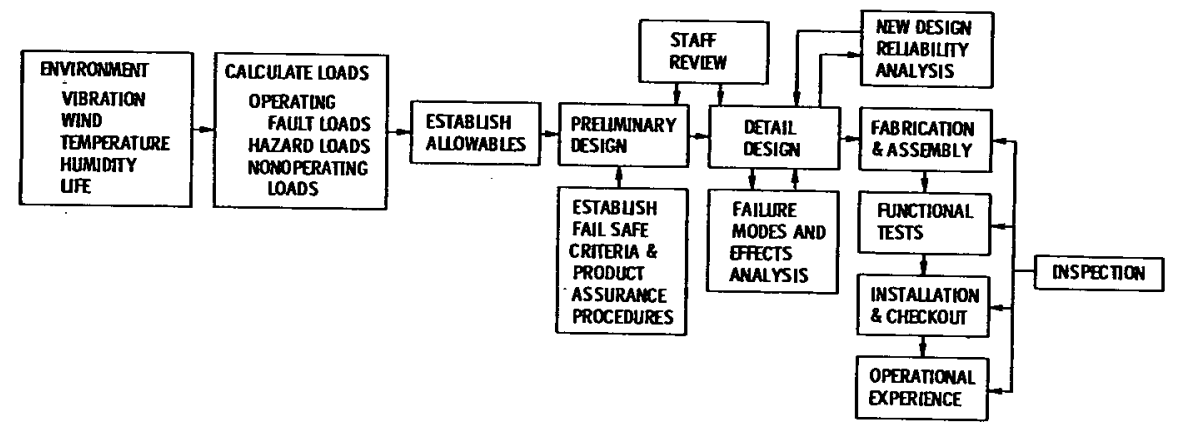

Figure 3. - Tangaye power system reliatility methodibogy 
Tab1e I - Solar cell power system design environment

\begin{tabular}{|l|l|l|l|}
\hline & \multicolumn{1}{|c|}{ Transportation } & Storage Installation & \multicolumn{1}{|c|}{ Operational } \\
\hline Duration & 3 weeks & 3 months & 5 years \\
\hline Wind & Negligible & Negligible & $96 \mathrm{mph}(160 \mathrm{~km} / \mathrm{hr})$ \\
\hline Vibration & $3 G$ & Negligible & Negligible \\
\hline $\begin{array}{l}\text { Temperature } \\
\text { Humidity, sand/ } \\
\text { dust, salt spray, } \\
\text { fungus }\end{array}$ & Same as operational & Same as operational & $\begin{array}{l}-40^{\circ} \mathrm{F}\left(-40^{\circ} \mathrm{C}\right) \text { to } 120^{\circ} \mathrm{F} \\
\left(48.9^{\circ} \mathrm{C}\right) \text { ambient air }\end{array}$ \\
\hline
\end{tabular}

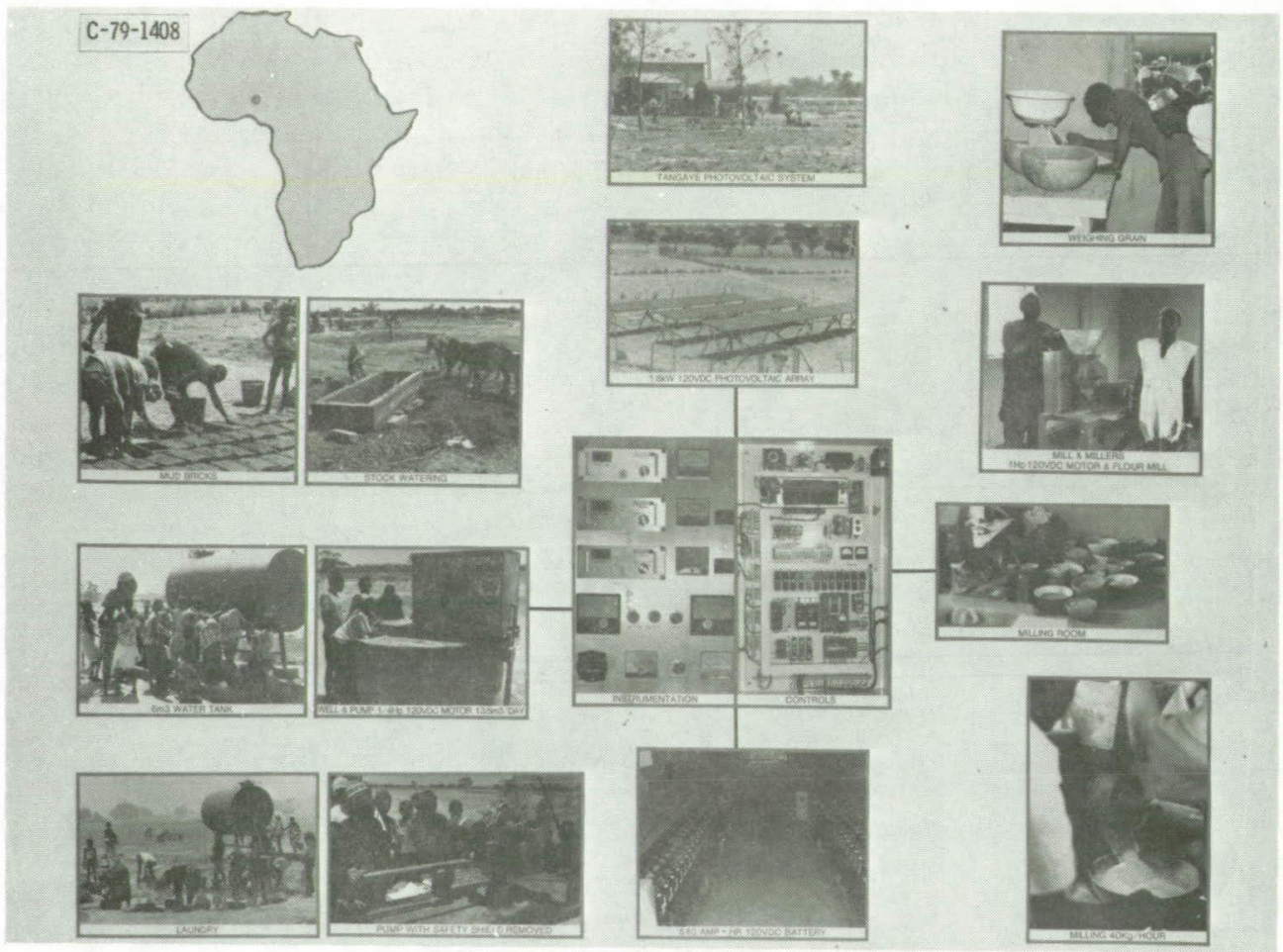

Figure I. - Village photovoltaic power system Tangaye, Upper Volta.

$$
\text { Co. } 1237344
$$




\begin{tabular}{|c|c|c|c|c|c|c|c|c|}
\hline Part & $\begin{array}{l}\text { Sumber } \\
\text { used }\end{array}$ & Stres: & Ret1ng & Operating & Ratio & $\begin{array}{c}\lambda_{b} \\
\left(\mathrm{FR} / 10^{6} \mathrm{hr}\right)\end{array}$ & T faetors & $\begin{array}{c}\lambda_{\mathrm{P}} \\
\left(\mathrm{FR} / 10^{6} \mathrm{hr}\right)\end{array}$ \\
\hline $\begin{array}{l}\text { Capacitor, } \\
\text { ceramic }\end{array}$ & 2 & $\begin{array}{l}\text { Voltage } \\
\text { Teoperature } \\
\text { vibration }\end{array}$ & $\begin{array}{c}-55^{\circ}{ }_{\text {to } 85^{\circ} \mathrm{C}}^{100 \mathrm{~V}} \\
20 \mathrm{G}\end{array}$ & $-40^{\circ}{ }_{36}^{15 v} 49^{\circ} \mathrm{c}$ & $\begin{array}{r}0.15 \\
.58 \\
.15\end{array}$ & 0.0028 & $\begin{array}{c}E Q \\
2 \text { Q } \\
\text { MI1-C-11015, Style CR }\end{array}$ & 0.1120 \\
\hline \multicolumn{7}{|c|}{ Re $\epsilon^{-t / \bar{t}}=0.919$ for a S-year wission } & $10^{6} / \sum_{p=1}^{0=9} \lambda_{p}=5.21 \times 10^{5} b x$ & $\sum_{-1}^{-9} \lambda_{p}=1.9210$ \\
\hline
\end{tabular}

Figure 4. Example Tangaye voltage regulator inherent reliability.

\begin{tabular}{|c|c|c|c|c|c|}
\hline Component & Pallure mode & Cause & Effect & Corrective action & Resarks \\
\hline Drum programber & $\begin{array}{l}\text { Sticking } \\
\text { W111 not step } \\
\text { W111 not swt teh }\end{array}$ & $\begin{array}{l}\text { Lack of lubricant } \\
\text { Motor, bear1ngs, shaft } \\
\text { Burned contacts }\end{array}$ & $\begin{array}{l}\text { Mumber of solar panels } \\
\text { cannot be changed. Main } \\
\text { battery could be dmanged. }\end{array}$ & $\begin{array}{l}\text { Clean and lubricate (moly } \\
\text { coat) main shaft bearings } \\
\text { every } 6 \text { monthe. Inspect } \\
\text { the interzupter cam every } \\
6 \text { months for wear ad lu- } \\
\text { bricate with aflicone } \\
\text { grease. Insect gwitch } \\
\text { contects for pitting or } \\
\text { corrosion every } 6 \text { months. } \\
\text { When badly pitted or cor- } \\
\text { roded, replace. }\end{array}$ & $\begin{array}{l}\text { This iteo has } \\
\text { ohortest life } \\
\text { in this design. } \\
\text { Consider remov- } \\
\text { ing this itea } \\
\text { and regulate } \\
\text { the array volt- } \\
\text { age using a PMM } \\
\text { circuit with } \\
\text { each panel. }\end{array}$ \\
\hline
\end{tabular}

Figure 5. - Example Tangaye failure modes and effects analysis. 


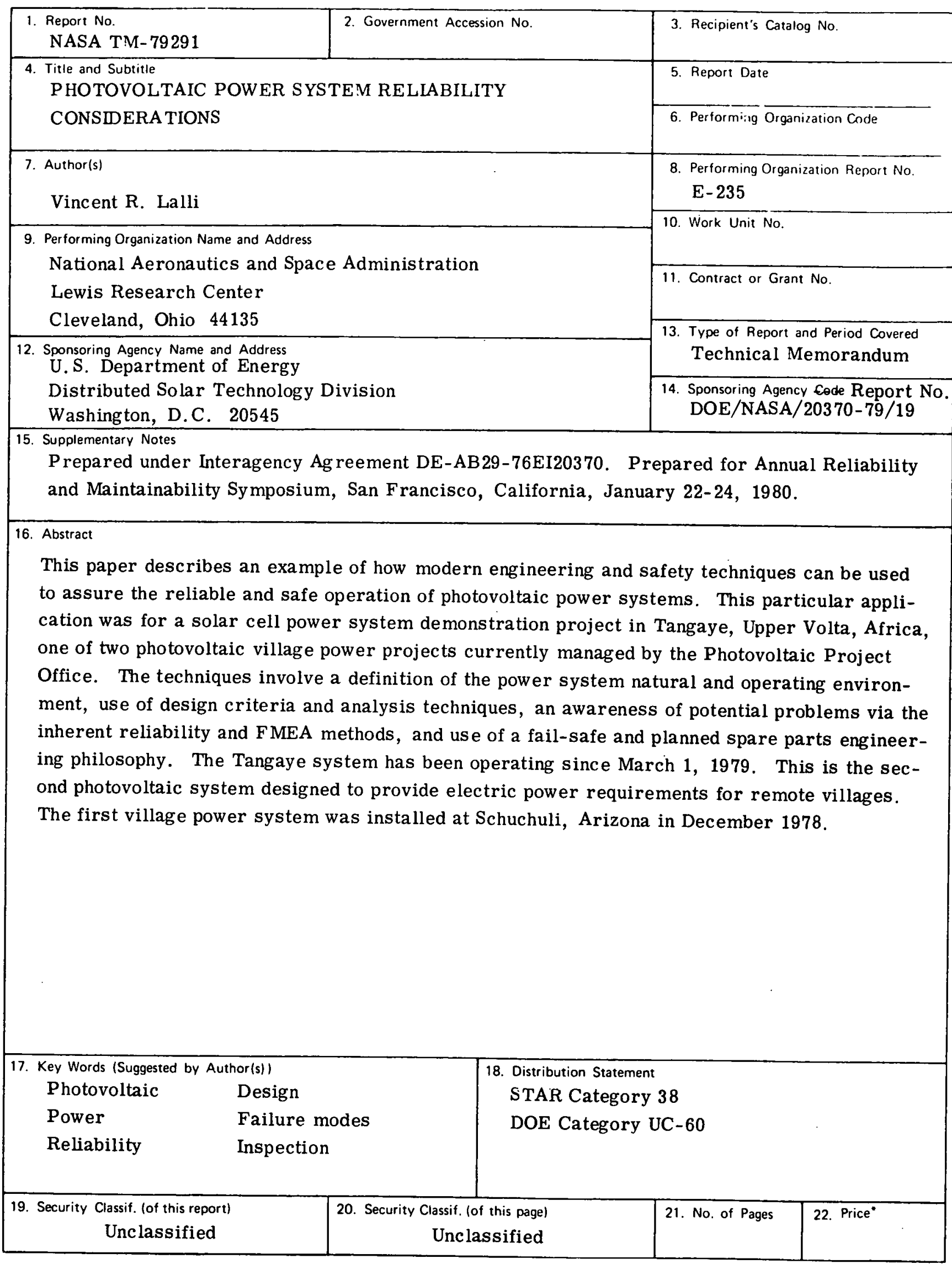

${ }^{*}$ For sale by the National Technical Information Service, Springfield, Virginia 22161 